\title{
DETOXICATION OF ALIPHATIC EPOXIDES BY DIOL FORMATION AND GLUTATHIONE CONJUGATION
}

\author{
J.E. SINSHEIMER, E. VAN DEN EECKHOUT*, B.H. HOOBERMAN and V.G. BEYLIN \\ College of Pharmacy, The University of Michigan, Ann Arbor, MI 48109 (U.S.A.). \\ (Received September 2nd, 1986) \\ (Reviaion recoived April 27th, 1987) \\ (Accepted April 27th, 1987)
}

\section{SUMMARY}

The Ames procedure with Salmonella typhimurium strain TA100 was used to follow the detoxication by rat liver fractions of two series of aliphatic epoxides. The epoxides employed were 3-chloro-, 3,3-dichloro and 3,3,3-trichloropropylene oxides and also p-methoxyphenyl-, phenyl- and $p$ nitrophenylglycidyl ethers. In our procedure with preincubation of the epoxides with rat liver fractions prior to the Ames tests, there was more detoxication of both systems by glutathione conjugation (non-enzymatic and transferase promoted) than by the hydrolase pathways. Non-enzymatic reaction with glutathione was more pronounced for the chloro series than for the glycidyl ethers. An HPLC system was developed which was capable of quantitative measurements of the phenylglycidyl ethers together with their diol and glutathione conjugate products. A comparison of the HPLC and Ames test results indicates that the glutathione transferase reported to be present in Salmonella could be playing a role in detoxication by the Ames test. Diols were measured more readily by HPLC than by use of the Ames test in the microsomal fraction and were detected in the cytosol with the glycidyl ethers while they were not by the Ames procedure. However, all three epoxides were converted to a greater extent to their glutathione conjugates than to their diols. Thus, while literature references question the availability of the glutathione detoxication system for epoxides produced by membrane-bound enzymes, such detoxication would be of primary importance where direct-acting environmental epoxides come into contact with the cytosolic enzymes prior to possible reaction with bionucleophiles.

Key words: Propylene oxides - Phenylglycidyl ethers - Epoxide hydrolase - Glutathione transferase

Abbreviations: DMSO, dimothylsulfoxide; GSH, glutathione; HPLC, high pressure liquid chromatography; S9, supernatant fraction after centrifugation at $9000 \times g, S 100$, supernatant after centrifugation at $100000 \times g$; TLC, thin-layer chromatography.

* On leave from Laboratoria voor Farmaceutiache Chemie en Ontleding van Geneesmiddelen, Rijksuniveraiteit - Gent, Harelbekestrant 72, B-9000 Gent, Belgium. 


\section{INTRODUCTION}

The toxicity of aliphatic epoxides is of concern due to their widespread use as important laboratory and industrial alkylating agents as well as to their role as possible intermediates in alkene metabolism [1,2]. Since the potential hazard presented by these epoxides would be dependant on their ability to react with their biological targets, such as DNA, it is also important to examine the ways in which these chemicals may be inactivated before they reach such targets. While comparative rates of detoxication of epoxides by microsomal hydrolase [3], cytosolic hydrolase [4] and glutathione-S-transferase [5] have been reported, detoxication studies in the presence of these systems simultaneously have not been described. This is especially important since Hayakawa et al. [5] have noted that a complementary relationship appears to exist between glutathione-S-transferase and microsomal epoxide hydrolase, in that compounds that are poor substrates for one system are good substrates for the other enzyme.

Previous work on aliphatic epoxides in this laboratory has centered on the study of structure-mutagenicity relationships for Salmonella typhimurium with several series of related compounds [6-10]. By extending this approach with the Ames test [11] to the study of detoxication, comparisons could be established between the relative efficacy of the competing enzyme systems to inactivate the epoxides in addition to examining the structural features that might play a role in the detoxication of epoxides. For the present investigation three representative compounds from two different series of aliphatic epoxides were selected for study. The first series consisted of the 3-chloro-, 3,3-dichloro- and 3,3,3-trichloropropylene oxides. The second series examined included 1,2-epoxy-3-phenoxypropane (phenyglycidyl ether) and its para-nitro and para-methoxy derivatives. These compounds were selected so as to give a wide range of mutagenicity, as determined by $S$. typhimurium strain TA100, and chemical reactivity, as measured by Taft and Hammett substituent constants [12,13].

In addition to the mutagenicity studies, HPLC methods were developed for the analysis of the diols and glutathione conjugates formed during the inactivation of the phenylglycidyl ethers. These more sensitive techniques permitted further examination of the extent to which aliphatic epoxides are detoxicated by enzymatic systems. Also since the Ames test is often run in the presence of liver homogenate fractions [11], it was of interest to compare detoxication effects promoted or modified by the Ames procedure to those measured by HPLC.

\section{MATERIALS AND METHODS}

\section{Chemicals}

1-Chloro-2,3-epoxypropane (epichlorohydrin), 1,2-epoxy-3,3,3-trichloropropane (trichloropropylene oxide), 1,2-epoxy-3-phenoxypropane (phenylglycidyl ether), 2,3-epoxypropyl 4-methoxyphenyl ether (p-methoxy- 
phenylglycidyl ether), 4-hydroxy propiophenone, 3-(4methoxyphenoxy)propane-1,2-diol and 4-(4-nitrobenzyl)pyridine were purchased from Aldrich Chemical Company, Inc. (Milwaukee, WI) and 1,2epoxy-3-(4-nitrophenoxy)propane (p-nitrophenylglycidyl ether) was purchased from Eastman Kodak Co. (Rochester, NY). The epoxides were purified by distillation or recrystallization.

3-Phenoxypropane-1,2-diol and 3-(p-nitrophenoxy)-propane-1,2-diol were synthesized by hydrolysis from their corresponding epoxides by a procedure described for the synthesis of p-nitrostyrene diol [12] and purified by preparative TLC using hexane/ethylacetate (3:7). The glutathione conjugates of 1,2-epoxy-3-phenoxypropane and 1,2-epoxy-3-(4-nitrophenoxy) propane were synthesized as we previously reported [15] for the conjugate of 1,2-epoxy-3phenoxypropane.

1,1-Dichloro-2,3-epoxypropane (dichloropropylene oxide) was prepared by the reaction of diazomethane and dichloroacetaldehyde. Diazomethane ( $\sim 0.7 \mathrm{~g}$ in $70 \mathrm{ml}$ of ether) was prepared from $5.0 \mathrm{~g}$ of $N$-methyl- $N$-nitroso-ptoluenesulfonamide (Diazald ${ }^{\star}$, Aldrich) using a Diazald kit and following the manufacturer's safety considerations! [16]. An ether solution $(10 \mathrm{ml})$ of $1.076 \mathrm{~g}(9.5 \mathrm{mmol})$ of dichloroacetaldehyde freshly prepared $[17,18]$ from diethyl acetal (Aldrich) was added dropwise to the diazomethane solution cooled by an ice bath. The mixture was allowed to reach room temperature and left overnight before the ether was distilled off by use of a water bath $\left(45-47^{\circ} \mathrm{C}\right)$ with the distilling apparatus from the Diazald kit for safety considerations and then followed for a short time by the use of a rotary evaporator. The crude mixture was purified by column chromatography [30 $\mathrm{g} \mathrm{SiO}, \mathrm{CH}_{2} \mathrm{Cl}_{2}$ /hexane (7:3) collecting 10-ml fractions]. Fractions 6 through 8 gave $0.6 \mathrm{~g}$ of the colorless product with boiling point $53-54^{\circ} \mathrm{C} / 30$ $\mathrm{mm}$ (lit. [10] $43-44^{\circ} \mathrm{C} / 20 \mathrm{~mm}$ ). An $R_{f}$-value of 0.58 was found on TLC using silica with $\mathrm{CH}_{2} \mathrm{Cl}_{2}$-hexane (7:3) and this spot gave a positive reaction with 4(4-nitrobenzyl)pyridine [19]. ' $\mathrm{H}-\mathrm{NMR}$ : (DMSO- $d_{6}, 60 \mathrm{MHz}$ ) $\delta, 6.1(\mathrm{~d}, 1 \mathrm{H}$, $\left.\mathrm{CHCl}_{2}\right), 3.6(\mathrm{~m}, 1 \mathrm{H}, \mathrm{CH}), 2.95\left(\mathrm{~m}, 2 \mathrm{H}, \mathrm{CH}_{2}\right) \cdot{ }^{13} \mathrm{C}-\mathrm{NMR}$ : (DMSO-d $\mathrm{d}_{6}, 22.5 \mathrm{MHz}$ ) $\delta, 72.27\left(\mathrm{~d}, \mathrm{CHCl}_{2}\right), 55.37(\mathrm{~d}, \mathrm{CH}), 46.98\left(\mathrm{t}, \mathrm{CH}_{2}\right)$.

\section{Chromatography}

Prescored $2 \times 10-\mathrm{cm}, 250-\mu$ silica gel GF Uniplates (Analtech, Newark, DE) were used for TLC to examine the purity of the epoxides and to monitor reactions. The TLC criteria of purity used for the epoxides was that $2 \mu \mathrm{l}$ of a $10 \%$ solution in methanol gave only one spot after development in dichloromethane-methanol systems and visualization under UV or upon reaction with 4-(4-nitrobenzyl)pyridine [19]. Solvent systems used to identify the glutathione conjugates were (A) $n$-butanol/n-propanol/ammonia $(1: 1: 1)$ and (B) methanol/ethanol/ammonia (30:68:2). Detection was by UV at $254 \mathrm{~nm}$ and by spraying with a $0.2 \%$ ninhydrin solution in ethanol followed by heating at $110^{\circ} \mathrm{C}$. The $R_{i}$-values for the glycidyl ethers for both systems were as follows: phenyl, (A) 0.42 and (B) 0.37; nitrophenyl, (A) 0.42 and (B) 0.31; methoxyphenyl, (A) 0.39 and (B) 0.33 . 
Analytical high pressure liquid chromatography (HPLC) with UV detec-

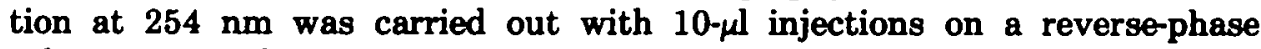
column (Partisil PXS 10/25 ODS-3, Whatman, Clifton, NJ) preceded by a guard column (4.6 $\times 50 \mathrm{~mm}$ packed with pellicular ODS, Whatman). The following mobile phases were used at a flow rate of $1.5 \mathrm{ml} / \mathrm{min}$ : (A) Ammonium formate $23 \mathrm{mM}$ (pH 5.13)/methanol (70:30) for the simultaneous quantitative determination of phenylglycidyl ether or $p$-methoxyphenylglycidyl ether, their diols and glutathione conjugates, (B) ammonium formate $23 \mathrm{mM}$ (pH 5.13)/methanol $(80: 20)$ for the quantitative determination of $p$-nitrophenylglycidyl ether, its diol and its glutathione conjugate, (C) phosphate buffer $66 \mathrm{mM}$ (pH 7)/methanol (90:10) for monitoring the synthesis of the glutathione conjugates of phenylglycidyl ether, $p$ methoxyphenylglycidyl ether and $p$-nitrophenylglycidyl ether.

\section{Liver homogenate fractions}

The S9 fraction was prepared from uninduced, male Sprague-Dawley rats $(180-200 \mathrm{~g})$ purchased from Charles River. The procedure was as described by Ames et al. [11]. A portion of the S9 was then centrifuged at $100000 \times g$ for $1 \mathrm{~h}$, the supernatant (S100, cytosol) decanted and saved, and the microsomal pellet washed in an equal volume of phosphate buffer (0.1 $\mathrm{M}, \mathrm{pH} \mathrm{7.4)}$ and recentrifuged at $100000 \times \mathrm{g}$ for $1 \mathrm{~h}$. The final microsomal fraction was obtained by decanting and discarding the supernatant and resuspending the pellet again in an equal volume of phosphate buffer. The fractions were divided into aliquots and stored at $-80^{\circ} \mathrm{C}$. All procedures were performed under sterile conditions. Protein content of these fractions was determined by the Lowry procedure [20].

\section{Mutagenicity assay}

S. typhimurium strain TA100 was obtained from Dr. Bruce Ames (University of California, Berkeley, CA). To prepare a culture for testing, nutrient broth was inoculated, allowed to sit overnight, then shaken in a $37^{\circ} \mathrm{C}$ water bath until it reached an absorbance of $0.75-0.85$ at $560 \mathrm{~nm}$.

The mutagenicity testing procedures were based on those described by Ames et al. [11] with the following modifications. A preincubation step was incorporated into the test to permit more control over the enzyme-epoxide reactions. In this step, $1.0 \mathrm{ml}$ of the appropriate liver fraction, previously diluted $1: 9$ in phosphate buffer, was combined in a $3.5 \mathrm{ml}$ tube with 0.100 $\mathrm{ml}$ of glutathione in phosphate buffer (to give a final concentration of 10 $\mathrm{mM}$ of glutathione) and $0.050 \mathrm{ml}$ of the epoxide in DMSO $(0.5 \mu \mathrm{mol}$ for the phenylglycidyl ethers, $1.0 \mu \mathrm{mol}$ for epichlorohydrin and $0.1 \mu \mathrm{mol}$ for dichloro- and trichloropropylene oxides). This mixture was incubated for $7 \mathrm{~min}$ at $37^{\circ} \mathrm{C}$ in a shaking water bath, the incubation stopped by immersing the tube into boiling water for $60 \mathrm{~s}$ and the tube placed on ice. For the phenylglycidyl ether series, $0.1 \mathrm{ml}$ of bacterial culture and $2.0 \mathrm{ml}$ of top agar were added to the tube, which was then mixed and poured onto minimal agar plates and incubated for 2 days at $37^{\circ} \mathrm{C}$, as in the standard plate incorpora- 
tion assay. For the propylene oxides, the liquid preincubation Ames assay was used due to the more volatile nature of these compounds with the following specifications. The bacterial culture $(1.5 \mathrm{ml})$ was added to the preincubation tubes which were then capped and incubated for $2 \mathrm{~h}$ in a shaking water bath at $37^{\circ} \mathrm{C}$. After incubation, the tubes were centrifuged at $9000 \times g$ for $10 \mathrm{~min}$, the supernatant discarded, and the pellet resuspended in $0.615 \mathrm{ml}$ of phosphate buffer. Aliquots of $0.200 \mathrm{ml}$ were removed and added to $2.0 \mathrm{ml}$ of top agar and plated. The plates were incubated for 2 days at $37^{\circ} \mathrm{C}$.

All plates were done in triplicate and each experiment was performed twice. Epoxide and glutathione solutions were prepared fresh on the day of the experiment, as were the liver fraction dilutions.

\section{Liver homogenate incubations for HPLC}

Rat liver fractions were diluted with phosphate buffer $(0.066 \mathrm{M}, \mathrm{pH}$ 7.4) to the following protein concentrations: $S 9(7.00 \mathrm{mg} / \mathrm{ml})$, microsomal fraction $(1.02 \mathrm{mg} / \mathrm{ml})$ and the cytosolic fraction $(4.76 \mathrm{mg} / \mathrm{ml})$. A $1-\mathrm{ml}$ portion of each fraction was allowed to equilibrate in glass stoppered tubes at $37^{\circ} \mathrm{C}$ for $2 \mathrm{~min}$ before the addition of $50 \mu \mathrm{l}$ of a DMSO solution $(20 \mathrm{mg} / \mathrm{ml})$ of the glycidyl ether substrates. For the determination of glutathione transferase activity, $1.5 \mathrm{mg}(5 \mu \mathrm{mol})$ of glutathione was added as a solution $(30 \mathrm{mg} / \mathrm{ml}$ water). The incubation times varied from 3 to $25 \mathrm{~min}$ at $37^{\circ} \mathrm{C}$ before stopping the reactions by boiling for $45 \mathrm{~s}$. The fractions were then immediately cooled in ice and 4-hydroxypropiophenone as the internal standard was added ( $50 \mu \mathrm{l}$ of $1 \mathrm{mg} / \mathrm{ml}$ DMSO solution) before centrifugation (9000 $\times g$ for $20 \mathrm{~min}$ ). Aliquots $(10 \mu \mathrm{l})$ were analyzed by HPLC. For each epoxide studied two standards were employed. Standard $1-$ to $1.0 \mathrm{ml}$ of the phosphate buffer, $50 \mu \mathrm{l}$ of each of the following solutions were added: epoxide $(5 \mathrm{mg} / \mathrm{ml}$ DMSO), its diol (10 mg/ml DMSO), glutathione conjugate (10 mg/ml DMSO) and hydroxypropiophenone $(1 \mathrm{mg} / \mathrm{ml} \mathrm{DMSO}$ ). Standard 2 - for the same volumes of solution twice the concentration of epoxide, diol and glutathione conjugate was employed.

\section{RESULTS AND DISCUSSION}

Detoxication measurements of chloropropylene oxides by Ames tests

Epoxides were selected so as to have a range of chemical activity as indicated by increasing Taft values [12] for increasing chloro substitution in the propylene oxide series and for increasing Hammett values [13] for methoxy, phenyl and nitro substituents of the glycidyl ethers. The effects of treatment with liver fractions on the mutagenic activity of the chloropropylene oxides in S. typhimurium strain TA100 are shown in Table I. Figure 1 illustrates the comparative effects of each treatment for the three compounds in this series in terms of percentage changes in the number of revertants per plate compared to the buffer-control treatment.

The Ames mutagenicity studies for the chloropropylene oxides (Table I 


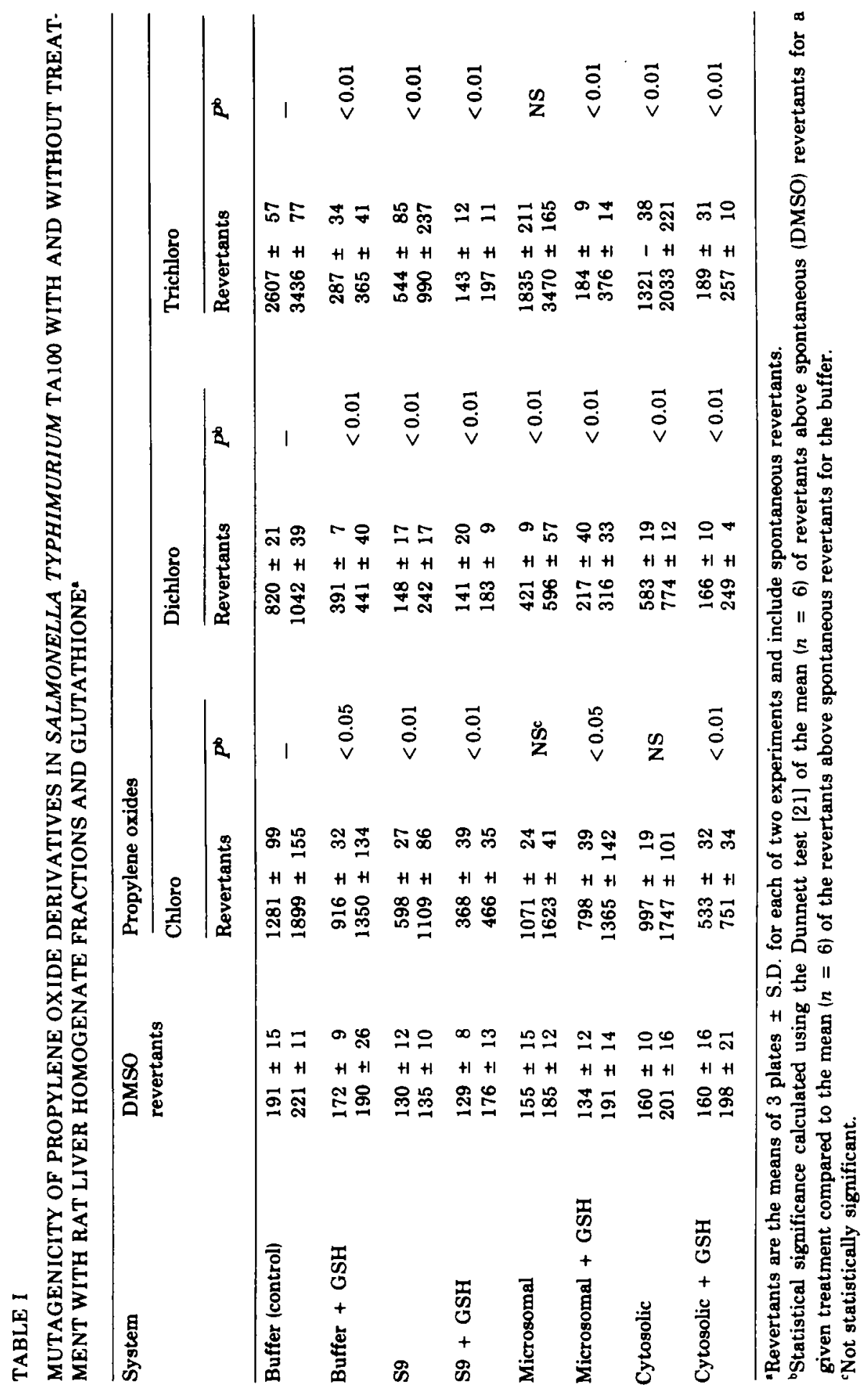




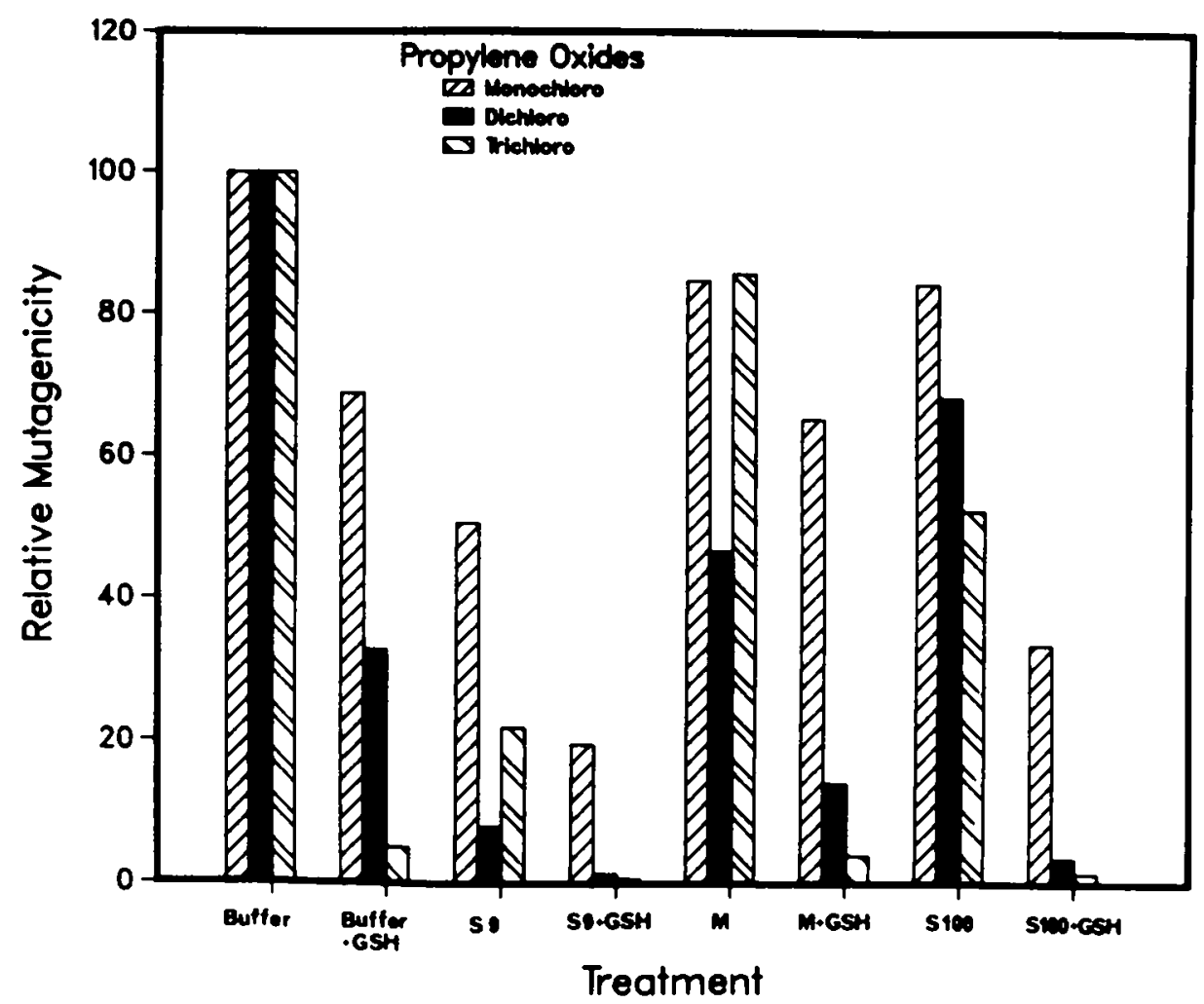

Fig. 1. Detoxication of propylene oxide derivatives in rat liver homogenate fractions as measured by the Ames preincubation test in TA100. Prior to the addition of bacteria, epoxides were incubated for $7 \mathrm{~min}$ at $37^{\circ} \mathrm{C}$ with $1.0 \mathrm{ml}$ of the appropriate liver fraction previously diluted $1: 9$ in phosphate buffer. Where indicated, the concentration of glutathione was $10 \mathrm{mM}$. The percentages are the means for the two trials of each system in Table I expressed as 100 (revertants for compound - spontaneous (DMSO) revertants) $\div$ (revertants for buffer - spontaneous revertants).

and Fig. 1) indicate considerable detoxication when just glutathione was added to the buffer.

This would be explained by non-enzymatic reaction of the epoxides with glutathione as well as by any reaction promoted by the glutathione transferase known to be present in Salmonella [22]. There is a pronounced decrease in mutagenicity upon the addition of rat liver S9 fractions. It is reasonable to postulate that a portion of this decrease can be assigned to membranebound hydrolase activity [3]. If this is true, such hydrolase activity should also be present with the addition of just the microsomal fraction. While this could be established on a statistically significant basis only for dichloropropylene oxide in the Ames test, our subsequent HPLC results established the presence of such membrane bound hydrolase detoxication in the microsomal fraction for the phenylglycidyl ethers. The additional detoxication in the S9 
and $\mathrm{S} 100$ fractions could be due to the glutathione transferase system with the presence of endogenous thiol substrates in these fractions and to the presence of soluble hydrolase [4]. The addition of glutathione to the S9 and S100 systems promoted the greatest detoxication. The decrease in mutagenicity in the microsomal system following the addition of glutathione is explained primarily on the basis of non-enzymatic reaction with glutathione. This is illustrated by comparison of this test to the test with buffer containing glutathione. It is of interest that the extent of detoxication in all the systems tested corresponded to the chemical reactivity of the epoxides as indicated by the Taft values of chloro substituents [12]. The exception is trichloropropylene oxide in the S9 and microsomal systems where this oxide is known to inhibit the hydrolase system [3]. While there is no such inhibition evident in the $\mathrm{S} 100$ system, it is known that trichloropropylene oxide is not an inhibitor for soluble hydrolase [4].

\section{Detoxication measurements of phenylglycidyl ethers by Ames testing}

A major difference in the phenylglycidyl ether series (Table II and Fig. 2) compared to the chloro compounds, is that less detoxication was noted in the S9 and S100 systems without added glutathione. In agreement with the chloro epoxides there is statistically significant evidence for non-enzymatic and/or bacterial glutathione transferase detoxication in the buffer system with glutathione. Ames test support for the presence of membrane-bound hydrolase activity in the glycidyl ether series is inconsistent. There is a statistically significant decrease in mutagenicity for only the methoxy derivative in the $\$ 9$ system and for the methoxy and phenyl derivatives in the microsomal system without added glutathione. The most efficient detoxication is with the S9 or S100 systems in the presence of excess glutathione. A correlation to chemical reactivity, as indicated by the Hammett values [13] of the para substituent, is not apparent for the mutagenicity studies of the glycidyl ether series.

\section{HPLC analysis of phenylglycidyl ethers and their metabolites}

The phenylglycidyl ethers could be followed in greater detail by HPLC analysis as the presence of the phenyl groups allowed for UV detection of this series. Reverse-phase systems with ammonium formate-methanol were developed which allowed for the separation and quantitation of epoxide, diol and glutathione conjugates in rat liver homogenate incubations. These systems were based upon our previously reported [15] HPLC separation of phenylglycidyl ether and its metabolites in rat liver incubations in which there were no apparent problems in the stability of the epoxides during their chromatography. The retention times expressed as capacity factors $\left(k^{\prime}\right)$ for the compounds of interest in these separations are summarized in Table III. There was no interference from the liver homogenates provided the incubation mixtures were deproteinated by boiling for $45 \mathrm{~s}$ followed by centrifugation. For each epoxide, control incubations were run as in the sample preparations but in previously boiled homogenate fractions. Under 


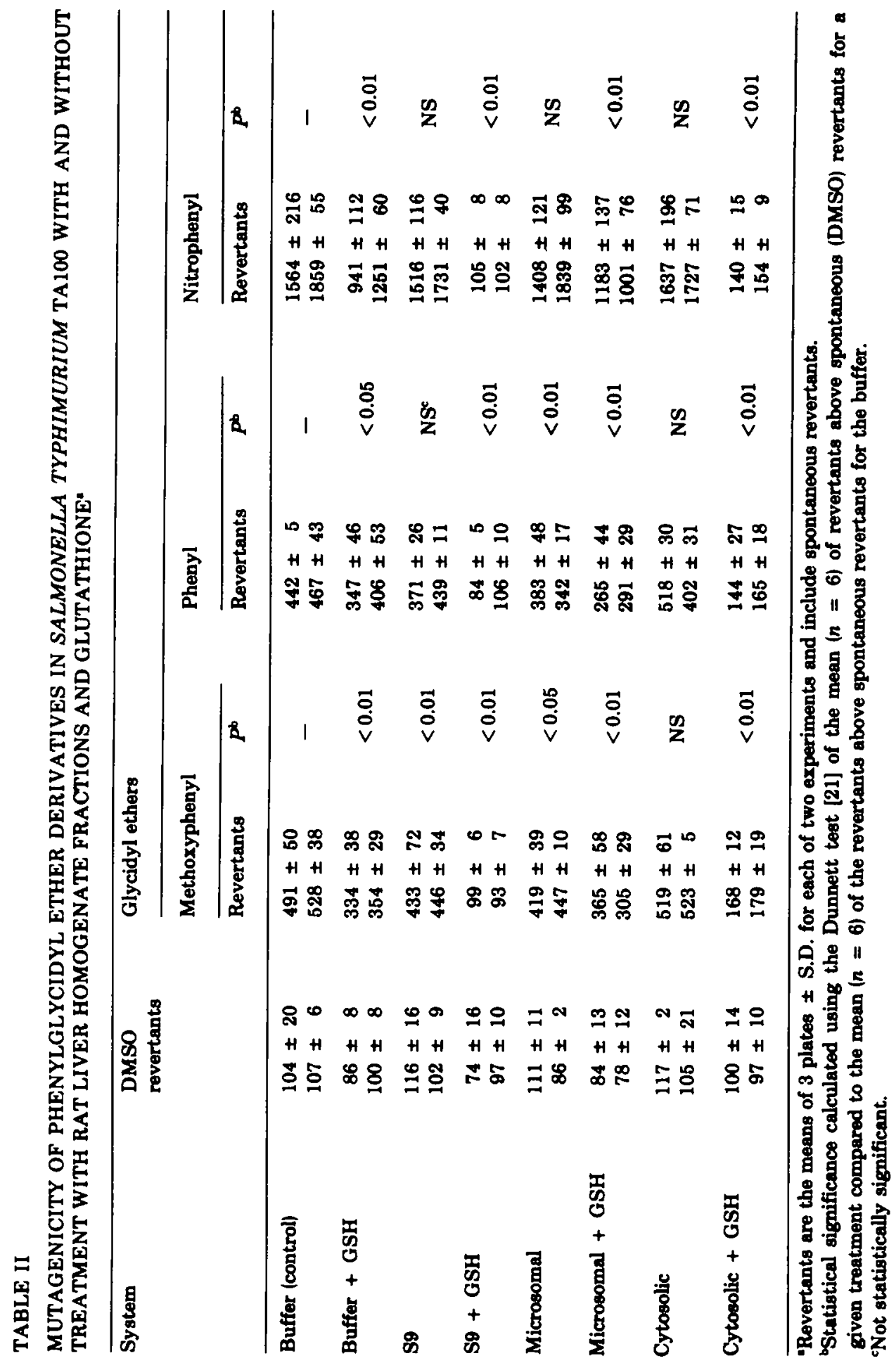




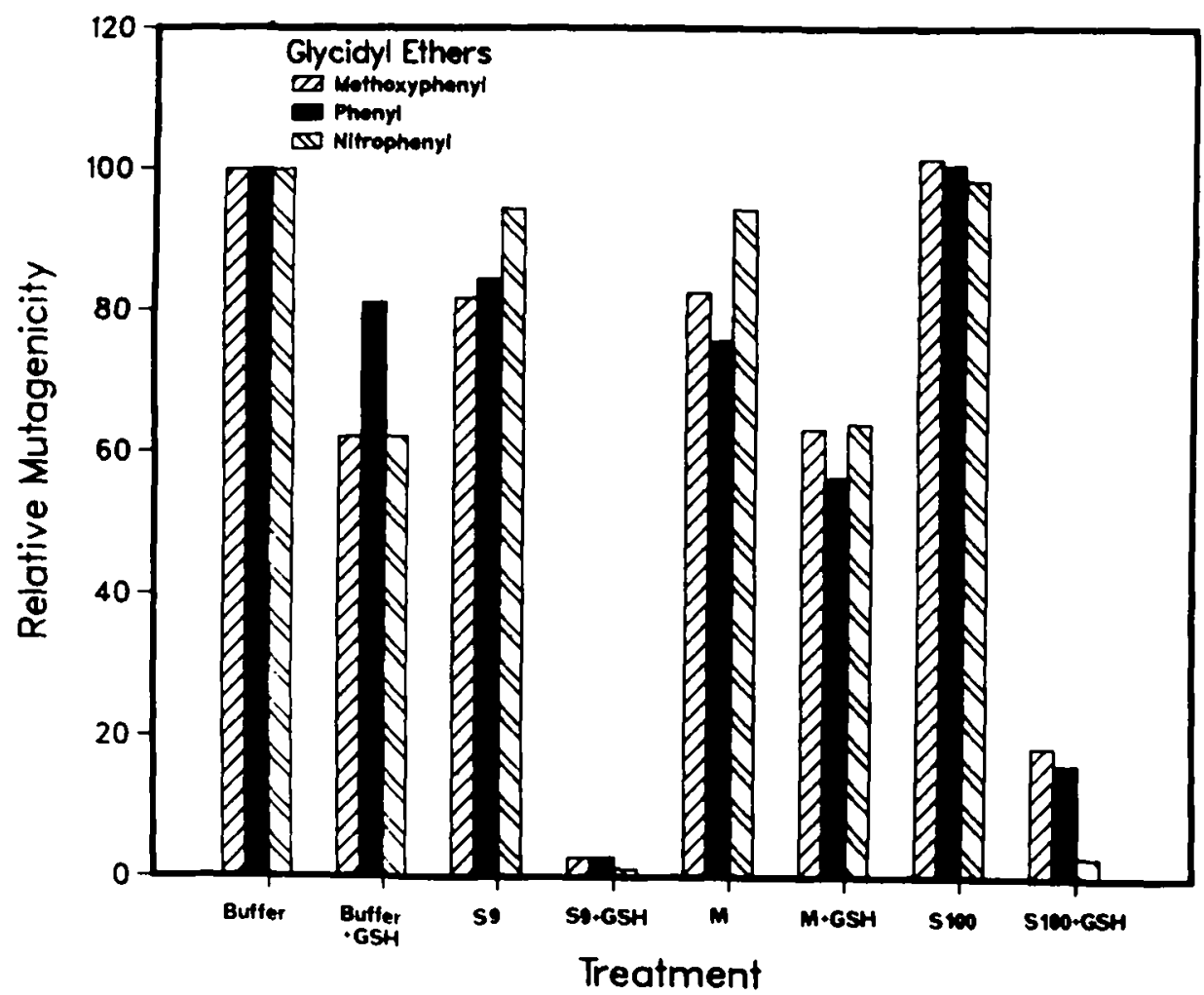

Fig. 2. Detoxication of phenylglycidyl ethers in rat liver homogenate fractions as measured by the Ames standard plate test in TA100. Prior to these tests, epoxides were incubated with the appropriate liver fractions as noted under Fig. 1. The percentages are the means for the two trials of each system in Table II expressed as 100 (revertants for compounds - sponteneous (DMSO) revertants) + (revertants for buffer - spontaneous revertants).

\section{TABLE III}

HPLC SEPARATION OF PHENYLGLYCIDYL ETHERS, GLUTATHIONE CONJU. GATES, DIOLS AND 4-HYDROXYPROPIOPHENONE

\begin{tabular}{lllc}
\hline Compounds & \multicolumn{2}{l}{ The $k^{\prime}$ values $^{a}$ for glycidyl ethers and their metabolites } \\
\cline { 2 - 4 } & $p$-Methoxyphenyl ${ }^{b}$ & Phenyl $^{b}$ & $p$-Nitrophenyl \\
\hline GSH conjugate & & 1.0 & 1.0 \\
Diol & 1.0 & 2.5 & 4.0 \\
4-Hydroxypropiophenone & 2.8 & 5.6 & 7.3 \\
Epoxide & 5.6 & 7.2 & 11.2 \\
\hline
\end{tabular}

' $k^{\prime}=\frac{t_{R}-t_{0}}{t_{0}}$ where $t_{0}=1.6 \mathrm{~min}$.

'Solvent A: ammonium formate $23 \mathrm{mM}$ (pH 5.13)/methanol (70:30).

'Solvent B: ammonium formate $23 \mathrm{mM}$ (pH 6.13)/mothanol (80:20). 
these control conditions, no diol formation was detected from the epoxides and only in the case of the strongest alkylating agent, nitrophenylglycidyl ether was non-enzymatic conversion $(16.6 \mathrm{nmol} / \mathrm{min} / \mathrm{mg})$ to the glutathione conjugate detected. This is in contrast to the Ames test results (Table II, Fig. 2) for all three epoxides where detoxication was observed in the presence of buffer with the addition of glutathione. This difference can be explained by the glutathione transferase present in Salmonella [22] promoting detoxication in the Ames assay but where this would not be a factor in the HPLC studies.

\section{Development of incubation procedures}

To compare the extent of detoxication by the epoxide hydrolase and glutathione transferase systems, apparent maximal velocities were determined for each compound in each system. First, product formation as a function of time was established and these values are summarized in Table IV. The S9, microsomal and cytosolic incubations were run in the presence and absence

\section{TABLE IV}

INFLUENCE OF INCUBATION TIME ON PRODUCT FORMATION WITH PHENYL GLYCIDYL ETHERS IN S9, CYTOSOLIC AND MICROSOMAL FRACTIONS^

\begin{tabular}{|c|c|c|c|c|c|}
\hline \multirow[t]{2}{*}{ Time (min) } & \multirow[t]{2}{*}{ S9 Diol } & \multicolumn{2}{|c|}{ S9 + GSH } & \multirow{2}{*}{$\begin{array}{l}\text { Micro- } \\
\text { somal } \\
\text { Diol }\end{array}$} & \multirow{2}{*}{$\begin{array}{l}\text { Cytosol + GSH } \\
\text { Conjugate }\end{array}$} \\
\hline & & Diol & $\begin{array}{l}\text { Congu- } \\
\text { gate }\end{array}$ & & \\
\hline \multicolumn{6}{|c|}{ Phenylglycidyl ether } \\
\hline 3 & 34.7 & 25.7 & 51.0 & 17.8 & 80.9 \\
\hline 5 & 58.4 & 43 & 84.5 & 30.5 & \\
\hline 6 & & & & & 157.4 \\
\hline 7 & 81.0 & 60.4 & 118.0 & 432.3 & \\
\hline 8 & & & & & 197.9 \\
\hline 10 & 106.7 & 86 & 160.3 & 620.5 & 281.1 \\
\hline 15 & 148.8 & 128.8 & 218.7 & 864.8 & 319.3 \\
\hline 20 & & & 255.1 & & 359.8 \\
\hline \multicolumn{6}{|c|}{ p-Methoxyphenylglycidyl ether } \\
\hline 3 & 28.5 & 21.6 & 38.1 & 183.6 & $\mathbf{5 4 . 0}$ \\
\hline 5 & 48.2 & 36.0 & 64.0 & 306.0 & 88.0 \\
\hline 7 & 63.1 & 45.0 & 72.2 & 350.1 & 100.0 \\
\hline 10 & 85.0 & 60.0 & 86.4 & 408.6 & 120.1 \\
\hline \multicolumn{6}{|c|}{ p-Nitrophenylglycidyl ether } \\
\hline 3 & 13.8 & 10.2 & 150.0 & 70.5 & 237.0 \\
\hline 5 & 15.8 & 10.3 & 235.8 & 141.0 & 333.0 \\
\hline 10 & 18.8 & 13.9 & 342.9 & 240.2 & 403.9 \\
\hline
\end{tabular}

'Yields are in nmol/mg protein for incubations at $37^{\circ} \mathrm{C}$ of $1-\mathrm{ml}$ dilutions of rat liver fractions having the following protein content: $S 9(7.00 \mathrm{mg})$ microsomes $(1.02 \mathrm{mg})$ and cytosol $(4.76 \mathrm{mg})$. Eporides were added as solutions of $1 \mathrm{mg} / 50 \mathrm{\mu l}$ of DMSO. In the measurements of glutathione transferase activity, $5 \mu \mathrm{mol}$ of ghutathione was used. 
of glutathione. The level of glutathione ( $5 \mu \mathrm{mol} /$ incubation) was chosen to obtain maximal yields without the danger of inhibiting the enzyme systems. This was based on the relationship of glutathione conjugate formation as a function of the quantity of glutathione added to the S9 and cytosolic fractions as reported in Table $V$ with phenylglycidyl ether as the primary substrate and with supporting data for the other epoxides. Without glutathione, no conjugate was detected but a reproducible and constant amount of conjugate is formed in the concentration range of 5-10 $\mu \mathrm{mol}$ glutathione per $1 \mathrm{ml}$ of rat liver homogenates per incubation. However, above this range there was definite inhibition so that at levels of $12.5 \mu \mathrm{mol}$ and higher, little or no conjugate could be detected.

For the homogenate systems of interest (S9 with and without added glutathione, microsomal fractions without glutathione and cytosolic fractions with added glutathione), substrate-concentration relationships were explored at $3 \mathrm{~min}$. This was on the linear portion of the product-time data for all the systems (Table IV). The product formation data as a function of substrate concentration are summarized in Table VI, with phenylglycidyl ether as the primary substrate and with supporting data for the other epoxides. Figure 3 describes the rate of product formation for the phenylglycidyl ethers in the S9 system with and without the presence of glutathione. These curves indicate about twice the yield of glutathione conjugate over diol when excess glutathione is present. Also, as might be expected, there is some decrease in diol when the epoxide is also reacting with glutathione as opposed to the diol yields in the absence of glutathione.

Comparison of diol and glutathione conjugate formation by HPLC

The more extensive comparison of product formation is presented in

TABLE V

INFLUENCE OF GLUTATHIONE ON CONJUGATE FORMATION IN S9 AND CYTOSOL FRACTIONS*

\begin{tabular}{|c|c|c|c|c|c|c|}
\hline \multirow{3}{*}{ 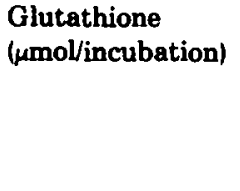 } & \multicolumn{6}{|c|}{ Glycidyl ethers } \\
\hline & \multicolumn{2}{|c|}{ Phenyl } & \multicolumn{2}{|c|}{$p$-Nitrophenyl } & \multicolumn{2}{|c|}{ p-Methoxyphenyl } \\
\hline & S9 & Cytosol & S9 & Cytosol & S9 & Cytosol \\
\hline 1.25 & 7.1 & & & & & \\
\hline 2.50 & 13.2 & & & & & \\
\hline 5.00 & 16.5 & 25.5 & 50.0 & 77.0 & 12.5 & 17.8 \\
\hline 10.00 & 17.5 & 25.7 & 50.1 & 78.0 & 12.2 & 17.7 \\
\hline 11.00 & 7.8 & 25.7 & 50.7 & 77.0 & 12.7 & 18.0 \\
\hline 12.50 & 0.3 & & & & & \\
\hline 20.00 & $0^{\circ}$ & & & & & \\
\hline
\end{tabular}

"Yield are in $\mu \mathrm{mol} / \mathrm{min} / \mathrm{mg}$ protein for $7 \cdot \mathrm{min}$ incubations as described in footnote" to Table IV. 
TABLE VI

PRODUCT FORMATION FROM THE PHENYLGLYCIDYL ETHERS IN RAT LIVER HOMOGENATE FRACTIONS AS A FUNCTION OF SUBSTRATE CONCENTRATION

\begin{tabular}{|c|c|c|c|c|c|}
\hline \multirow{2}{*}{$\begin{array}{l}\text { Substrate } \\
\text { Conc. (nM) }\end{array}$} & \multirow[t]{2}{*}{ S9 Diol } & \multicolumn{2}{|c|}{ S9 + GSH } & \multirow{2}{*}{$\begin{array}{l}\text { Cytosol + } \\
\text { GSH Con- } \\
\text { jugate }\end{array}$} & \multirow{2}{*}{$\begin{array}{l}\text { Microsomal } \\
\text { Diol }\end{array}$} \\
\hline & & Diol & $\begin{array}{l}\text { Conju- } \\
\text { gate }\end{array}$ & & \\
\hline \multicolumn{6}{|c|}{ Phenylglycidyl ether } \\
\hline 6 & 3.50 & 2.10 & 3.20 & & \\
\hline 12 & 7.00 & 7.35 & 6.00 & & \\
\hline 18 & 11.00 & 6.45 & 9.00 & & \\
\hline 30 & 11.00 & 8.55 & 17.30 & 25.30 & 70.68 \\
\hline 42 & & & & 25.99 & 70.68 \\
\hline 48 & 11.00 & 8.55 & 17.40 & 25.99 & 70.70 \\
\hline 60 & & & & 26.91 & 74.46 \\
\hline \multicolumn{6}{|c|}{ p-Methoxyphenylglycidyl ether } \\
\hline 25 & 9.45 & 7.05 & 12.6 & 17.71 & 60.45 \\
\hline 50 & 9.60 & 7.05 & 12.9 & 17.71 & 59.52 \\
\hline \multicolumn{6}{|c|}{ p-Nitrophenylglycidyl ether } \\
\hline 46.9 & 4.50 & 3.30 & 79.50 & 77.74 & 23.25 \\
\hline 93.9 & 4.50 & 3.15 & 49.95 & 76.82 & 24.18 \\
\hline
\end{tabular}

Yield are in $\mu \mathrm{mol} / \mathrm{min} / \mathrm{mg}$ protein for $7 \cdot \mathrm{min}$ incubations are described in footnote ${ }^{\mathrm{a}}$ to Table IV.

Table VII where the data from Table VI were used to establish the conditions of enzyme saturation by the substrates. The concentrations of substrates actually employed to obtain such saturation were methoxyphenylglycidyl ether $(50 \mathrm{mM})$, phenylglycidyl ether $(48 \mathrm{mM})$ and nitrophenylglycidyl ether ( $46.9 \mathrm{mM})$. Table VII gives the apparent maximal velocities expressed in terms of $\mu \mathrm{moles}$ of product $/ \mathrm{min} / \mathrm{g}$ equivalent of original liver so that yields of products from the various liver fractions might be compared. These values can be converted to apparent maximal velocities expressed in $\mu \mathrm{mol} / \mathrm{min} / \mathrm{mg}$ of protein by use of the factors included with the table.

Table VII shows that diol formation could be detected in both the microsomal and cytosolic fractions. However, the low levels of soluble hydrolase in rat liver did not allow for a rigorous treatment of the data since at $3 \mathrm{~min}$ the enzymatic reaction was already completed but with minimal HPLC response. With nitrophenylglycidyl ether as the substrate, where the overall yield of diol was the lowest, the distribution of diol from the two sources was comparable. While the Ames test results for methoxyphenyl and phenylglycidyl ethers support the presence of microsomal hydrolase (Table II, Fig. 2), they underestimate the contribution of this source of detoxication in contrast to the ratio of diol to glutathione conjugate yields shown by HPLC 


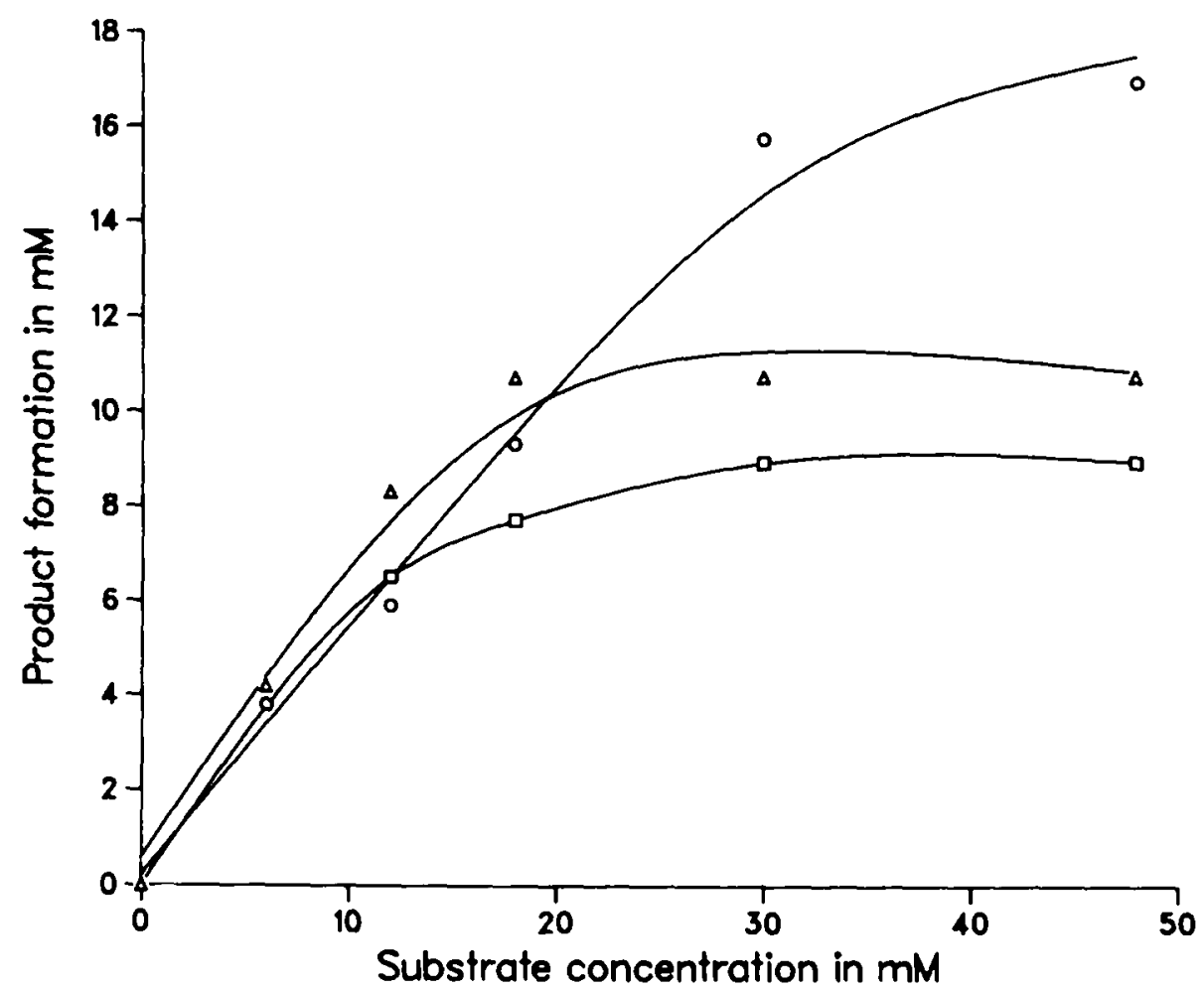

Fig. 3. Product formation curves from phenylglycidyl ether in 59 with and without glutathione as a function of substrate concentration. $\square$, diol formation when glutathione had been added; $\Delta$, diol formation in the absence of added glutathione; $O$, glutathione conjugation when glutathione had been added. Incubations were for $7 \mathrm{~min}$ at $37^{\circ} \mathrm{C}$ with $1 \mathrm{ml}$ of an 59 dihution $(7$ mg protein). Where indicated, $5 \mu \mathrm{mol}$ of glutathione was added.

(Table VII) and lack the sensitivity to confirm the presence of the lower levels of soluble hydrolase. As was illustrated in Fig. 3 for phenylglycidyl ether in the S9 fraction, all three epoxides were converted to a greater extent to their glutathione conjugates than to their diols. The ratio of conjugate to diol yields in the S9 fraction range from somewhat less than 2 to 1 for the methoxy compound to 15 to 1 for the nitrophenylglycidyl ether. Glutathione conjugation in the cytosolic fraction accounts for this production of conjugates. The analytical measurements for glutathione conjugate formation are in basic agreement with the Ames mutagenicity tests for the glycidyl ethers. They extend the Ames test results by assigning a lesser role to nonenzymatic detoxication and by establishing a positive relationship between chemical activity of the phenylglycidyl ethers, as indicated by the Hammett values of the para substituents, and detoxication.

El-Tantawy and Hammock [23] were not able to show any increase in epoxide detoxication for styrene oxide, allylbenzene oxide or 4-chlorophenylglycidyl ether by glutathione as compared to detoxication by soluble 
TABLE VII

PRODUCT FORMATION FROM PHENYLGLYCIDYL ETHERS BASED UPON THE WEIGHT OF RAT LIVER USED FOR HOMOGENATE FRACTIONS ${ }^{\star}$

\begin{tabular}{|c|c|c|c|c|}
\hline \multirow[t]{2}{*}{ Enzyme systems } & \multirow[t]{2}{*}{ Products } & \multicolumn{3}{|c|}{ Glycidyl ethers } \\
\hline & & $\begin{array}{l}\text { p-Methory- } \\
\text { phenyl }\end{array}$ & Phenyl & $\begin{array}{l}\text { p-Nitro- } \\
\text { phenyl }\end{array}$ \\
\hline S9+ GSH & $\begin{array}{l}\text { GSH conjugate } \\
\text { Diol }\end{array}$ & $\begin{array}{l}0.84 \pm 0.09 \\
0.47 \pm 0.05\end{array}$ & $\begin{array}{l}1.15 \pm 0.12 \\
0.57 \pm 0.06\end{array}$ & $\begin{array}{l}3.30 \pm 0.33^{b} \\
0.22 \pm 0.02\end{array}$ \\
\hline \$9 & $\begin{array}{l}\text { GSH conjugate } \\
\text { Diol }\end{array}$ & $\begin{array}{l}\overline{0}^{c} \\
0.63\end{array} 0.07$ & $\overline{-}^{c}$ & $\begin{array}{l}0.07 \pm 0.05^{b} \\
0.30 \pm 0.03\end{array}$ \\
\hline $\begin{array}{l}\text { Microsomal } \\
\text { Cytosol + GSH }\end{array}$ & $\begin{array}{l}\text { Diol } \\
\text { GSH conjugate }\end{array}$ & $\begin{array}{l}0.65 \pm 0.06 \\
0.77 \pm 0.08\end{array}$ & $\begin{array}{l}0.76 \pm 0.08 \\
1.10 \pm 0.12\end{array}$ & $\begin{array}{l}0.25 \pm 0.03 \\
3.38 \pm 0.34^{b}\end{array}$ \\
\hline & Diol & $0.17 \pm 0.04^{d}$ & $0.21 \pm 0.04^{d}$ & $0.21 \pm 0.04^{d}$ \\
\hline
\end{tabular}

These values (mean $n=5 \pm$ S.D.) are in $\mu \mathrm{mol} / \mathrm{min} / \mathrm{g}$ original liver and can be converted to $\mathrm{nmol} / \mathrm{min} / \mathrm{mg}$ protein by multiplying by the following factors: 15 for S9, 93 for microsomes and 23 for cytosol. Incubations were for $7 \mathrm{~min}$ under the conditions of footnote to Table IV.

bNon-enzymatic product formation detected in the boiled controls was subtracted from these values.

'No ghutathione conjugate detected.

While these values show evidence for the presence of soluble eporide hydrolase, the absolute values are in doubt because of the low level of enzyme present and reduced HPLC peak heights.

hydrolase with the use of mouse liver cytosol in the Ames procedure. However, there is a difference in their use of the Ames procedure in that they add glutathione and liver fractions directly to the Ames plates after the addition of substrates and bacteria for reaction in the agar media. In our use of the Ames tests for both the chloropropylene oxides and phenylglycidyl ethers, reaction of substrates was with glutathione in the presence of the enzyme systems in a manner analogous to the tests used with HPLC analysis and before the addition of bacteria and agar. As noted by Glatt and Oesch [24], the topographical situation in the cell becomes an important consideration for glutathione detoxication. As these investigators point out for highly lipophilic reactive metabolites produced in the endoplasmic reticulum, the cytosolic enzymes may be of limited value for detoxication. However, our results may be more consistent with the detoxication of direct acting environmental epoxides if there is contact with the cytosolic enzymes prior to reaction with bionucleophiles.

\section{ACKNOWLEDGEMENTS}

The authors wish to express their appreciation to Dr. Bruce Ames, University of California at Berkeley, for supplying the Salmonella strain TA100. This research was supported by Grant No. R01 ES 03345 from the National Institute of Environmental Health Sciences. 


\section{REFERENCES}

1 M.M. Manson, Epoxides - Is there a human health problem?, Br. J. Ind. Med., 37 (1980) 317.

2 L. Ehrenberg and S. Hussain, Genetic toxicity of some important epoxides, Mutat. Res., 86 (1981) 1 .

3 F. Oesch, Epoxide hydratase, in: G.W. Bridges and L.F. Chasseaud (Eds.), Progress in Drug Metabolism, Wiley, New York, 1979, pp. 253-303.

4 S.S. Gill and B.D. Hammock, Distribution and properties of a mammalian soluble epoxide hydrase, Biochem. Pharmacol., 29 (1980) 389.

5 T. Hayakawa, S. Udenfriend, H. Yagi and D.M. Jerina, Substrates and inhibitors of hepatic glutathione-S-epoxide transferase, Arch. Biochem. Biophys., 170 (1975) 438.

6 D.R. Wade, S.C. Airy and J.E. Sinsheimer, Mutagenicity of aliphatic epoxides, Mutat. Res., 58 (1978) 217.

7 S.W. Frantz and J.E. Sinsheimer, Bacterial mutagenicity and toxicity of cycloaliphatic epoxides, Mutat. Res., 90 (1981) 67.

8 S.H. Neau, B.H. Hooberman, S.W. Frantz and J.E. Sinsheimer, Substituent effects on the mutagenicity of phenylglycidyl ethers in Salmonella typhimurium, Mutat. Res., 93 (1982) 297.

9 S.W. Frantz, E. Van den Eeckhout, J.E. Sinsheimer, M. Yoshihara and M. Koreeda, Mutagenicity of Salmonella assays of cyclohexane epoxide derivatives, Toxicol. Lett., 25 (1985) 265.

10 L.B. Rosman, V.G. Beylin, V. Gaddamidi, B.H. Hooberman and J.E. Sinsheimer, Mutagenicity of para-substituted a-methylstyrene oxide derivatives with Salmonella, Mutat. Res., 171 (1986) 63.

11 B.N. Ames, J. McCann and E. Yamasaki, Methods for detecting carcinogens and mutagens with the Salmonella/mammalian-microsome mutagenicity test, Mutat. Res., 31 (1975) 347.

12 R.W. Taft, Separation of polar and steric effects in reactivity, in: M.S. Newman (Ed.), Steric effects in Organic Chemistry, Wiley, New York, 1957, pp. 556-659.

13 D.H. McDaniel and H.C. Brown, An extended table of Hammett substituent constants based on the ionization of substituted benzoic acids, J. Org. Chem., 23 (1958) 420.

14 R.B. Westkaemper and R.P. Hanzlik, A convenient reverso-phase liquid chromatographic assay for epoxide hydrase, Anal. Biochem., 102 (1980) 63.

15 E. Van den Eeckhout, J.E. Sinsheimer, W. Baeyens, D. DeKeukeleire, A. De Bruyn and P. De Moerloose, Regioselectivity in the chemical and enzymatic reactions between ghutathione and phenylglycidyl ether, Analyt. Lett., 16 (1983) 785.

16 T.H. Black, The preparation and reactions of diazomethane, Aldrichem. Acta, 16 (1983) 3.

17 H. Lerche, J. Treiber and Th. Severin, Umsetzung $\mathrm{CH}$-acider verbindungen mit dichloracetaldehyd-oxim zu (hydroxyimino)ethyliden-derivaten, Chem. Ber., 113 (1980) 2796.

18 A. Wohl and H. Roth, Uber a,a-dichlor-isopropyl-alkohol und die darstellung des dichloraldehyds, Chem. Ber., 40 (1907) 212.

19 L.G. Hammock, B.D. Hammock and J.E. Casida, Detection and analysis of epoxides with 4-(p-nitrobenzyl)pyridine, Bull. Environ. Contam. Toxicol., 12 (1974) 759.

20 O.H. Lowry, N.J. Rosebrough, A.L. Farr and R.J. Randall, Protein measurement with the folin-phenol reagent, J. Biol. Chem., 193 (1951) 265.

21 C.W. Dunnett, A multiple comparison procedure for comparing several treatments with a control, J. Am. Stat. Assoc., 50 (1955) 1096.

22 K-H. Summer, W. Goggelmann and H. Greim, Glutathione S-transferases in the Salmonella mammalian-microsome mutagenicity test, Mutat. Res., 70 (1980) 269.

23 M.A. El-Tantawy and B.D. Hammock, The effect of hepatic microsomal and cytosolic subcellular fractions on the mutagenic activity of epoxide-containing compounds in the Salmonella assay, Mutat. Res., 79 (1980) 59.

24 H. Glatt and F. Oesch, Inactivation of electrophilic metabolites by glutathione S-transferase and limitation of the system due to subcellular localization, Arch. Toxicol., 39 (1977) 87. 